\title{
Description of a new species of the genus Leporinus Spix (Characiformes: Anostomidae) from the rio Araguaia, Brazil, with comments on the taxonomy and distribution of $L$. parae and $L$. lacustris
}

\author{
Heraldo A. Britski and José L. O. Birindelli
}

\begin{abstract}
A new species of the genus Leporinus is described from the rio Araguaia, in Mato Grosso and Goiás states, Brazil. The new species has the dental formula 4/3, a unique feature within the genus; all other species of Leporinus have dental formulae 3/3, $3 / 4$ or $4 / 4$. In addition, the new species can also be distinguished by the following combination of characters: 36 to 37 scales in the lateral line, $4 / 4.5$ or $4 / 5$ series of scales in the transversal line, 16 circumpeduncular scale series, anal fin surpassing base of lower caudal-fin rays and three blotches along the lateral line. The new species shares with L. parae and L. lacustris a rather deep body, terminal mouth, long anal fin, three small dark blotches on the lateral line, the latter two, particularly the last one, usually fading, and preference for lentic habitats. Comments on the taxonomy and distribution of the species $L$. parae and $L$. lacustris are provided.
\end{abstract}

Uma nova espécie do gênero Leporinus é descrita do rio Araguaia, nos estados do Mato Grosso e Goiás, Brasil. A característica mais notável da nova espécie é sua fórmula dental 4/3, única entre as espécies do gênero que possuem fórmula dental 3/3, 3/ 4 ou 4/4. A nova espécie também pode ser reconhecida pela combinação das seguintes características: 36 a 37 escamas na linha lateral, 4/4,5 ou 4/5 séries de escamas na linha transversal, 16 series de escamas circumpedunculares, nadadeira anal ultrapassando a base dos raios inferiores da nadadeira caudal e presença de três manchas escuras ao longo da linha lateral. A nova espécie compartilha com L. parae e L. lacustris corpo alto, boca terminal, nadadeira anal longa e escura, três manchas escuras na linha lateral pequenas, sendo as duas últimas, em especial a última, geralmente apagadas, e preferência por habitats lênticos. Além disso, são feitos comentários sobre a taxonomia e a distribuição de L. parae e L. lacustris.

Key words: Leporinus venerei, Tocantins, Anostomoidea, Ostariophysi.

\section{Introduction}

In 1995, Paulo Cesar Venere sent to Museu de Zoologia da Universidade de São Paulo (MZUSP) a collection of fishes made by himself in the rio Araguaia, eastern region of Mato Grosso, central Brazil, including different species of the genus Leporinus. This collection included three specimens of an undescribed species with a unique number of teeth in the jaws; however, considering the small number of specimens available, this species was not described at that time. In the year of 2005, another lot of this new species was deposited at MZUSP, with three specimens collected in the same area by members of the Central Brazilian Expedition (CBE). Since the new species was rediscovered, we contacted Paulo Cesar Venere who recently collected a few more specimens. On the basis of this material now in hands the new species can now be appropriately described.
The first paper on Leporinus from the rio Tocantins basin (including the rio Araguaia drainage) comes from Valenciennes (1850) who, based on material collected by Castelnau, described L. pachyurus and mentioned L. obtusidens and $L$. maculatus. Other papers by Castelnau (1855), Borodin (1929), Garavello (1979), Santos et al. (1984), Santos \& Jégu (1989), Britski (1997), Garavello \& Britski (2003), and Santos et al. (2004), reported a total of 18 species of Leporinus for the rio Tocantins basin, including two new species currently under description by Garavello \& Santos (Garavello, pers. com.). This makes the rio Tocantins one of the richest in species of the genus Leporinus among all South American river basins.

\section{Material and Methods}

Counts and measurements follow Britski \& Garavello (1978), and Britski \& Garavello (2005). The number of teeth is ex-

Museu de Zoologia da Universidade de São Paulo, Caixa Postal 42494, 04299-970, São Paulo, SP, Brazil. heraldo@usp.br; jbirindelli@yahoo.com 
pressed as a dental formula and represents the premaxillary number over the dentary counts in each half of the jaw. Counts of vertebrae were taken from radiographed specimens. Vertebral counts included the four vertebrae of the Weberian apparatus and the fused PU1+U1 of the caudal region (counted as a single vertebra). Lateral-line scale counts included the pored scales extending onto the base of the median caudalfin rays. Upper scale counts of transversal series represents the number of scale rows between the median dorsal row and the lateral line (i.e., the count starts at a point just in front of the dorsal-fin origin, and not at the dorsal-fin base, and does not include the median dorsal row); this procedure always eliminates the very confusing count of a half scale in this series. A half scale between the lateral line and the pelvic fin is only counted when the base of the pelvic-fin first ray faces the middle of the scale immediately in front of it. Meristic data of the holotype are indicated in the text by an asterisk. Institutional abbreviations includes: ANSP, Academy of Natural Sciences of Philadelphia; MZUSP, Museu de Zoologia da Universidade de São Paulo and USNM, United States Nation Museum, Smithsonian Institute.

\section{Results}

\section{Leporinus venerei, new species}

Fig. 1

Holotype: MZUSP 93124 (113.3 mm SL), Mato Grosso, São Felix, Lake in Fazenda Entre-Rios (approx. $11^{\circ} 35^{\prime} \mathrm{S} 50^{\circ} 40^{\prime} \mathrm{W}$ ), 24 Oct 2006; P. C. Venere \& C. E. de Melo.

Paratypes: MZUSP 93123 (8, 82.5-105.8 mm SL), collected with holotype. MZUSP 92027 (3, 103.1-114.3 mm SL), Goias, Aruanã, Fazenda Sobrado, pool at margin of road between Aruanã and Cocalinho (1445'30"S 50³7' 50"W), 25 Jul 2005; C. Chamon, L. Sousa, M. Melo \& L. Souza. MZUSP 93125 (3, 92.2-106.4 mm SL), Mato Grosso, Araguaiana, Córrego and Cacimbas (borrow pits) at Fazenda do Italiano (approx. $15^{\circ} 43^{\prime} \mathrm{S} 51^{\circ} 51^{\prime} \mathrm{W}$ ), $06 \mathrm{Jul} 1995$; P. C. Venere \& C. E. Melo. MZUSP 93122 (6, 98.1-135.5 mm SL), Mato Grosso, Araguaiana, Ribeirão Dois de Agosto, tributary of rio Pindaíba, rio das Mortes drainage (approx. $\left.15^{\circ} 15^{\prime} \mathrm{S} 51^{\circ} 45^{\prime} \mathrm{W}\right), 30$ Jun 1992; P. C. Venere \& C. E. Melo.

Diagnosis. Leporinus venerei is distinguished from its congeners by having 4 teeth on the premaxilla and 3 teeth on the dentary yielding the dental formula $4 / 3$ (vs. $3 / 3,3 / 4$ or $4 / 4$ in all other species of Leporinus). Leporinus venerei is also diagnosed by the following combination of non-unique characteristics: presence of 36-37 pored scales in the lateral line, 4 scales in transversal series from origin of dorsal fin to lateral line and 4.5 to 5 scales from lateral line to base of pelvic fin; 16 series of scales around caudal peduncle; three round dark blotches on lateral line, the first at vertical through dorsal fin, the second at vertical through adipose-fin origin and the third at base of caudal peduncle (the latter two blotches, particularly the last one, usually small or inconspicuous).
Comparisons. Leporinus parae Eigenmann, 1907, and L. lacustris Campos, 1945, are most similar in overall appearance (body shape and coloration) to $L$. venerei, but both species have dental formula $4 / 4$ (vs. 4/3 in L. venerei). In addition L. parae has 38 to 41 and L. lacustris 33 to 35 lateralline scales (vs. 36-37 in L. venerei) and L. parae has 5 scales in transverse series from lateral line to dorsal-fin origin (vs. 4 in L. venerei).

Description. See Table 1 for morphometric data of 21 examined specimens and Fig. 1 for lateral view of holotype. Small sized species for genus Leporinus, largest examined specimen $135.5 \mathrm{~mm}$ SL. Body rather elevated and compressed. Dorsal profile straight from anterodorsal portion of snout to posterior tip of supraoccipital; straight or very slightly convex from that point to dorsal-fin origin; straight along dorsalfin base; slightly convex or straight from dorsal-fin base to adipose fin and slightly concave from adipose fin to caudalfin origin. Ventral profile slightly convex from tip of lower jaw to pelvic-fin insertion, (convexity less pronounced below branchial region in some specimens); straight from pelvic-fin base to anal-fin origin; straight at anal-fin base and concave from anal fin to caudal fin. Greatest body depth at origin of dorsal fin. Head somewhat compressed; mouth terminal, anterior opening of mouth positioned at horizontal bisecting eye.

Premaxillary with four teeth diminishing in size laterally from the symphyseal tooth. Dentary with three teeth also decreasing in size laterally. Teeth on both jaws of stair-step type.

Dorsal-fin rays $\mathrm{ii}+11$ * or $\mathrm{iii}+11$; dorsal-fin origin slightly in front of vertical through pelvic-fin origin; dorsal-fin base extending through seven or eight scales. Pectoral-fin rays $i+13,14 *$ or 15 ; pectoral fin extending to third or fourth scale anterior to pelvic-fin base. Pelvic-fin rays $i+8$; pelvic fin extending to four or five scale posterior to fin base. Anal-fin rays ii-9 or iii $+9 *$; anal fin clearly surpassing base of lower caudal-fin rays; distal margin of anal fin straight or slightly convex. Length of last anal fin ray 26 to $47 \%$ (mean 36\%) length of first branched anal-fin ray. Caudal-fin rays $\mathrm{i}+17+\mathrm{i}$; caudal fin forked, upper lobe slightly more developed than lower lobe. Vertebrae $34(\mathrm{n}=4)$ to $35(3)$.

Scales with few radii (5-7). Lateral line complete with 36 (5) to $37^{*}(13)$ perforated scales; transversal series with 4 (21)

Table 1. Morphometric data of Leporinus venerei.

\begin{tabular}{lccccc}
\hline & $\mathrm{n}$ & Mean & Range & SD & Holotype \\
\hline $\begin{array}{l}\text { Standard length (mm) } \\
\text { Percentages of SL }\end{array}$ & 21 & 102.5 & $82.5-135.5$ & & 113.3 \\
Body depth & 21 & 33.4 & $30.8-35.9$ & 1.53 & 33.8 \\
Caudal-peduncle depth & 21 & 12.7 & $11.6-13.7$ & 0.46 & 12.7 \\
Head length & 21 & 27.1 & $24.6-29.0$ & 1.11 & 27.5 \\
Predorsal distance & 21 & 48.7 & $46.7-51.2$ & 1.01 & 49.1 \\
Preventral distance & 21 & 52.4 & $50.4-54.4$ & 1.12 & 52.8 \\
Pectoral-fin length & 20 & 18.3 & $16.8-19.5$ & 0.66 & 18.5 \\
Pelvic- fin length & 21 & 20.0 & $17.8-22.0$ & 0.91 & 19.9 \\
Percentages of HL & & & & & \\
Eye diameter & 21 & 28.4 & $23.8-33.0$ & 2.35 & 28.6 \\
Snout length & 21 & 38.6 & $35.9-40.8$ & 1.47 & 38.6 \\
Interorbital distance & 21 & 48.4 & $43.0-53.4$ & 3.01 & 46.0 \\
\hline
\end{tabular}




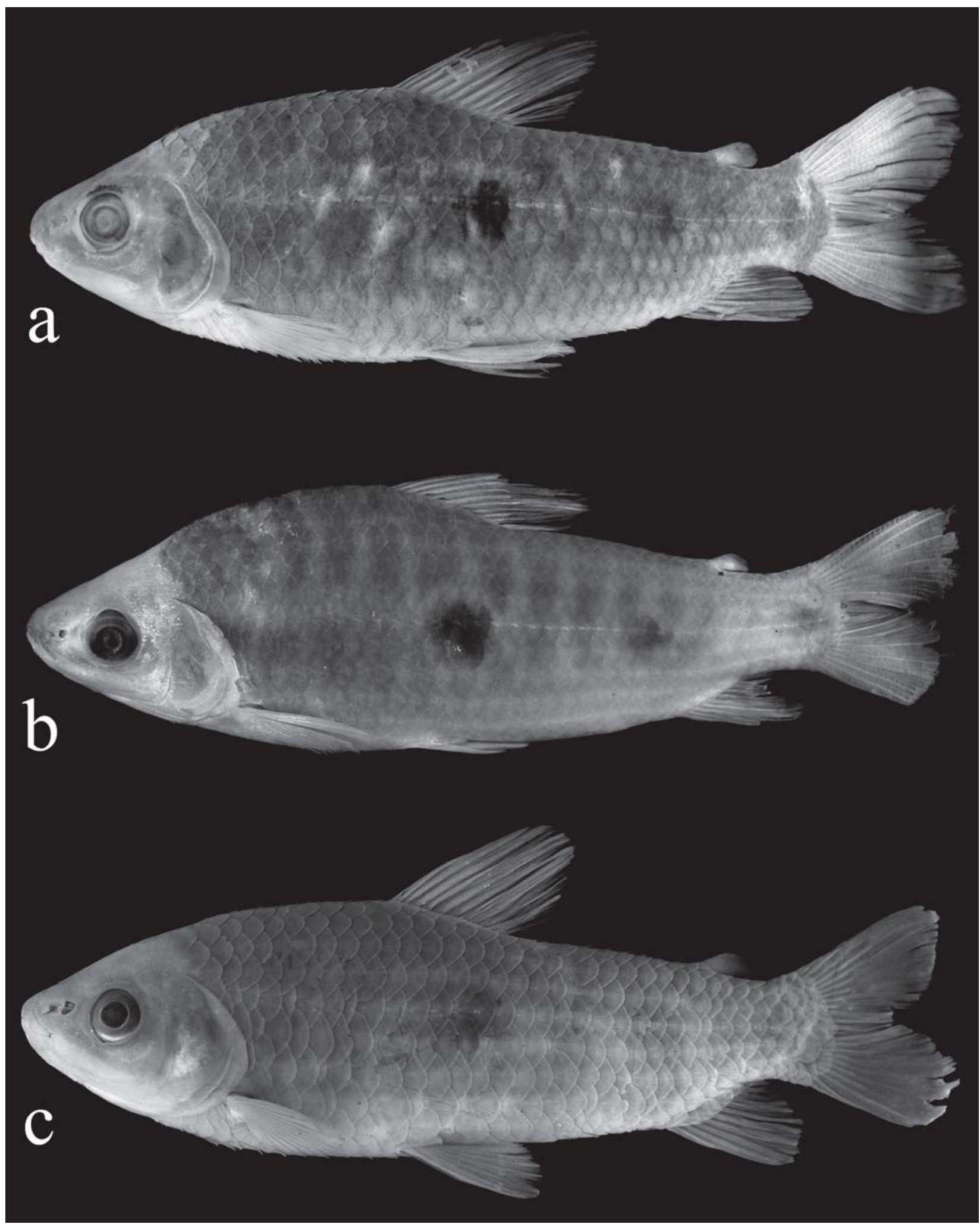

Fig. 1. Photograph in lateral view of (a) Leporinus venerei (holotype, MZUSP 93124, $113.3 \mathrm{~mm}$ SL), (b) Leporinus parae (MZUSP 48445, $111.9 \mathrm{~mm} \mathrm{SL}$ ), and (c) Leporinus lacustris (MZUSP 48414, $95.0 \mathrm{~mm} \mathrm{SL}$ ).

scales from dorsal-fin origin to lateral line and $4.5(6)$ to $5^{*}$ (15) scales from lateral line to pelvic-fin base; $9,10^{*}$ or 11 predorsal scales; 10 to $12 *$ scales in median dorsal row be- tween dorsal fin and adipose fin; $7^{*}$ or 8 scales in median dorsal row between adipose fin and caudal fin; 14 to $18^{*}$ prepelvic scales; $9,10^{*}$ or 11 scales in median ventral row 
between pelvic fin and anus; $1,2 *$ or 3 scales in median ventral row between anus and anal fin; 6 to $7 *$ scales in median ventral row between anal fin and caudal fin; 16 horizontal scale rows around caudal peduncle.

Coloration in alcohol. Overall ground color tan. Dorsal surface of head with small, dark-brown chromatophores uniformly scattered or concentrated in some areas, forming faint transverse bars: one at level of nares, another at level of interorbital space and sometimes a, barely visible pair of bars, each one starting on the lateral portion of posterior bar and extending anteriorly into interorbital area. Lateral and ventral surfaces of head pale, without chromatophores, except the bright silver opercular series; sometimes with a black blotch on its ventral portion. Body gradually darker from lateral line dorsally. Three dark blotches on lateral line: first blotch at vertical through posterior half of dorsal-fin base; second at level of the fifth or sixth scale anterior to adipose fin base and third at base of caudal peduncle; only first blotch usually conspicuous; second and third blotches generally reduced in size, faded or, occasionally, completely absent. Brown chromatophores bordering posterior edge of each scale giving a relatively gray reticulated aspect to body ground coloration. Some individuals with faint transverse bars on dorsum occasionally extended onto ventral portion of body. With exception of anal and adipose, remaining fins nearly hyaline with few chromatophores along margins of rays; anal fin dark brown, sometimes with whitish areas along its posterior margin; adipose fin usually whitish near base and dark brown distally.

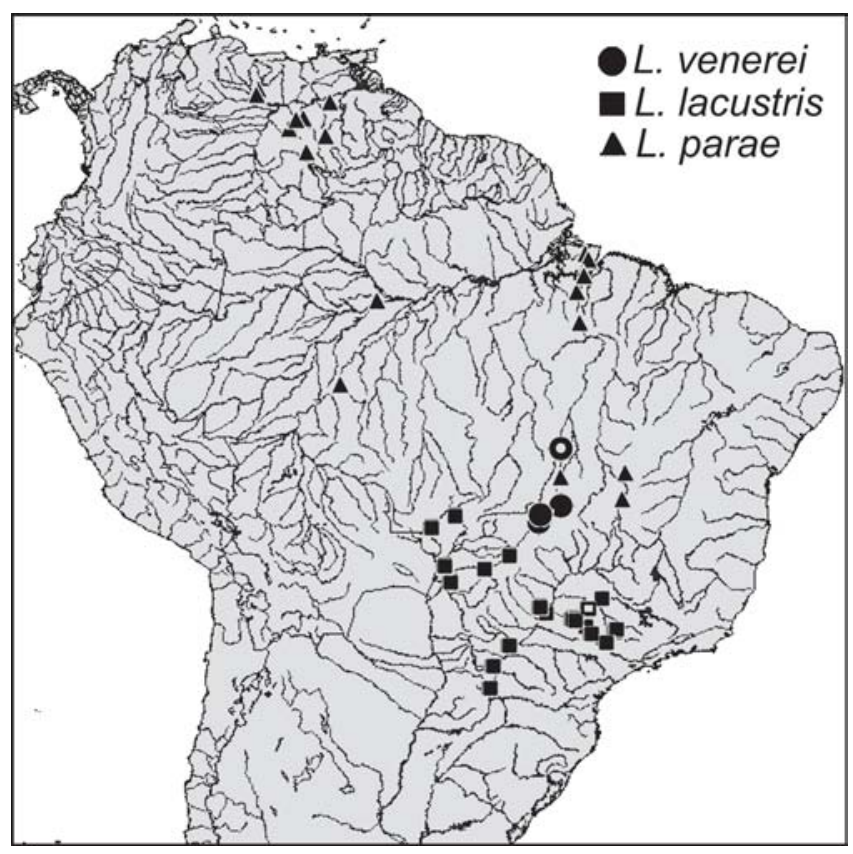

Fig. 2. Map of South America, showing the distribution of Leporinus venerei (dots), Leporinus parae (triangles) and Leporinus lacustris (squares); open symbols indicates typelocalities.
Distribution. The new species is only known from the rio Araguaia basin in Mato Grosso and Goiás states in central Brazil (see Fig. 2).

Ecological note. Leporinus venerei is found in lentic environments such as lagoons or borrow pits.

Etymology. The name venerei is given in honor to Paulo Cesar Venere who collected the first known specimens of this new species.

\section{Discussion}

The number of teeth in species of the genus Leporinus as discussed by Britski (1997), is a very important feature for the species diagnoses. The species of Leporinus are characterized by having three or four teeth on each premaxilla and dentary and, with the exception of the new species all of them can be placed into three artificial groups according to dental formula (i.e., species with $3 / 3,3 / 4$ or $4 / 4$ dental formulae). We have been working exhaustively on Leporinus, examining hundreds of specimens of different species and we have found that variation in dental formula among co-specific individuals is exceptional. In most cases, discrepant individuals were considered anomalous because their teeth were asymmetric (i.e., having either one more or one less tooth on only one side of upper or lower jaw); discrepancy involving both sides of jaws was found only in few examined specimens of $L$. taeniatus from the rio São Francisco basin. This consistency in number of teeth in species of Leporinus strengthens the reliance of this character in species diagnoses. In addition, we consider it important to provide a list of known species of Leporinus grouped by dental formula:

Dental formula 3/3: L aguapeiensis, L.amblyrhynchus, L.conirostris, L.crassilabris, L.desmotes, L.despaxi, L.elongatus, L.jatuncochi, L.macrocephalus, L.muyscorum, L.obtusidens, L.pachyurus, L.reinhardti, L.silvestri, L.trifasciatus, and L.wolfei.

Dental formula 3/4: L.amae, L.bahiensis, L.bistriatus, L.garmani, L.marcgravii, L.megalepis, L.melanopleura, L.microphthalmus, L.octofasciatus, L.octomaculatus, L.paranensis, L.reticulatus, L.sexstriatus, L.striatus, L.taeniatus, L.taeniofasciatus, L.tigrinus, and L.uatumaensis.

Dental formula 4/4: L.acutidens, L.affinis, L.agassizi, L.alternus, L.arcus, L.aripuanensis, L.bimaculatus, L.boehlkei, L.brunneus, L.copelandii, L.cylindriformes, L.ecuadorensis, L.falcipinnis, L.fasciatus, L.friderici, L.gomesi, L.gossei, L.granti, L.holostictus, L.julii, L.klausewitzi, L.lacustris, L.lebaili, L.maculatus, L.melanosticus, L.moralesi, L.mormyrops, L.multifasciatus, L.nattereri, L.niceforoi, L.nigrotaeniatus, L.nijsseni, L.ortomaculatus, L.pachycheilus, L.parae, L.paralternus, L.pearsoni, L.pellegrinii, L.piau, L.pitingai, L.punctatus, L.spilopleura, L.steindachneri, L.steyemarki, L.subniger, L.thayeri, L.trimaculatus, L.vanzoi, and L.yophorus. 
The following species have a doubtful number of teeth or the number of teeth is unknown: L. badueli, L. bleheri, $L$. jamesi, and L. latofasciatus.

We note that collectors must preserve specimens of Leporinus with mouth open, as they tend to close them very strongly when fixed in formaldehyde. Attempts at opening the mouth of fishes when so fixed usually lead to the breakage of the jaws, particularly the lower jaw, causing loss of the small lateral teeth and therefore making teeth counts unreliable.

There is no consistent hypothesis about relationships within species of Leporinus, a genus with large number of species presenting a great degree of variation in mouth position, tooth morphology and arrangements. Attempts to split Leporinus into subgenera (for example Borodin, 1929) are not presently accepted. Nevertheless, it is necessary to make some comments on similarities between the new species, Leporinus parae Eigenmann, and L. lacustris Campos. The latter two species share with $L$. venerei a deep body, terminal mouth, anal fin long and dark, and the three blotches on the lateral line small, with the latter two, particularly the last one, usually fading.

Leporinus parae Eigenmann, 1907 was described from the lower Amazon basin in Para state, Brazil. Measurements and counts were taken from 73 of the 279 examined specimens of $L$. parae from different localities (see comparative material which includes type material). This species is diagnosed by dental formula $4 / 4,38$ ( $n=22$, including the type), 39 (52), 40 (9), and 41 (1) scales in the lateral line, 5/5 transversal series of scales, and 16 circumpeduncular series of scales (Fig. 1). These data are in agreement with the original description (Eigenmann \& Ogle, 1907: 8); but, one of these characters differs from the text figure presented by those authors, as it shows a specimen with four series of scales between the lateral line and the dorsal fin. This should be interpreted as an inaccuracy of the drawer, since the type and all three cotypes have 5 scale series above the lateral line. Specimens of $L$. parae were found to occur throughout the Amazon and Orinoco basins (see comparative material, fig. 2). In some fish collections, specimens from the Orinoco were previously identified as L. subniger Fowler, 1943, described from the Colombian Amazon. Leporinus subniger resembles L. parae in the terminal mouth, dental formula $4 / 4$, and 16 series of scales in the caudal peduncle. Nevertheless, L. parae can be differentiated from $L$. subniger by the number of scales in the lateral line, 38 to 41 (vs. 36 to 38 in L. subniger), 5/5 scales in transversal line [vs. 4/4; although Fowler (1943) mentioned 5/5 scales in transversal line in L. subniger, our examination and that of Garavello (1979), confirmed that there are in fact 4/4 scales series in the transversal line in that species], three dark blotches sometimes fading [vs. three dark blotches always present and supplemented by several smaller blotches over body, see Fowler (1943: figs 10-12 for drawings), or Böhlke (1958: plate 6, fig. 2 for a photographed specimen)], and deep body and short head (vs. body relatively shallower and head relatively larger).

Leporinus lacustris Campos, 1945 was described from the upper rio Paraná basin in São Paulo state, Brazil. Measurements and counts were taken from 109 of the 152 examined specimens of L. lacustris from the upper rio Paraná and rio Paraguay basins (see comparative material which includes type material, fig. 2). The species is diagnosed by having dental formula 4/4, $33(n=4), 34$ (69, including the type), or 35 (36) scales in the lateral line, $4 / 4$ or $4 / 5$ transversal series of scales, and 16 circumpeduncular series of scales (Fig. 1). When describing L. lacustris Campos (1945:155) did not comment on the number of teeth and reported 3.5 scales in transverse series above lateral line and 32 to 34 scales in the lateral line. By our counts, the types have 4 and 33 to 34 scales, respectively. In addition, L. lacustris has fewer vertebrae $(33, \mathrm{n}=6)$, when compared to $L$. venerei $\mathrm{n} . \mathrm{sp}$. (34 to $35, \mathrm{n}=7$ ) and $L$. parae ( 35 to $37, \mathrm{n}=6$ ).

It is also worth mentioning that to our knowledge these three species are the only in the genus that show preferences for lentic habitats.

Comparative material examined. Leporinus parae: Brazil (Amazon drainage): USNM 034613 (holotype: $74.6 \mathrm{~mm} \mathrm{SL}$ ), Pará, J. C. Brevoort. USNM 306340 (paratype: $62.8 \mathrm{~mm} \mathrm{SL}$ ), USNM 34575 (paratypes, 2: 71.8-123.0 mm SL), same data as holotype. ANSP 8222 (1: 73.7 mm SL), Pará, M. Sculte-Buckow. MZUSP 3717 (1: 205.0 mm SL), MZUSP 3732 (5: 91.4-106.0 mm SL), Lago Arari, Pará, Oct 1944, A. A. Campos. MZUSP 5022 (2: 92.0-100.3 mm SL), Cachoeira do Arari, Ilha de Marajó, Pará, 12 Jun 1966, Exp. Depto. Zool. MZUSP 6524 (9: 76.5-124.5 mm SL), Lago Manacapuru, Amazonas, 12-13 Dec 1967, H. A. Britski. MZUSP 31401 (1: 157.8 mm SL), rio Madeira, Calama, Rondônia, Oct 1980, M. Goulding. MZUSP 40850 (4: 78.2-103.0 mm SL), intermittent tributary of rio Bezerra, Arraias, Tocantins, 10 Jan 1989, J. C. Oliveira \& W. J. M. Costa. MZUSP 40925 (2: 116.7-133.1 mm SL), Poço Gandaia, marginal lagoon of rio Paranã, Flores de Goiás, Goiás, 21 Jan 1989, J. C. Oliveira \& W. J. M. Costa. MZUSP 48444 (2: 136.6-142.3 mm SL), Amazonas and Pará, E. Garbe. MZUSP 48445 (10: 56.7-123.5 mm SL), rio Arari, Cachoeira do Arari, Ilha de Marajó, Pará, Jul 1965, N. A. Menezes. MZUSP 48703 (1: $149.7 \mathrm{~mm} \mathrm{SL})$, Creek on the $11^{\text {th }} \mathrm{km}$ of road Tucuruí Mato Grosso, Pará, 22 Sep 1970, Expedição Permanente à Amazônia (EPA). MZUSP 48716 (46: 66.6-174.2 mm SL), Igarapé Oxipucu, tributary of rio Tocantins, Mocajuba, Pará, 08 Sep 1970, EPA. MZUSP 48785 (70: 57.4-105.2 mm SL), Lagoa of rio Tocantins in Canal do Capitariquara, Jatobal, Pará, 18 Sep 1970, EPA. MZUSP 48726 (48: 58.2-116.3 mm SL), Lagoa of rio Tocantins, Jatobal, Pará, 16 ep 1970, EPA. MZUSP 48728 (2: 186.0-218.0 mm SL), Paranã Sumuuma, on mouth of rio Tocantins, Pará, 04 Sep 1970, EPA. MZUSP 48760 (6: 80.4-113.2 mm SL), Igarapé Limão, tributary of rio Tocantins, Baião, Pará, 09 Sep 1970, EPA. MZUSP 52355 (1: $86.6 \mathrm{~mm} \mathrm{SL}$ ), rio Araguaia, at beach between Bandeirantes and Luiz Alves, Goiás, Jul 1997, R. S. A. Matias. MZUSP 53730 (1: $89.3 \mathrm{~mm} \mathrm{SL}$ ), rio Araguaia, Lago das Branquinhas, Mato Grosso, Feb 1998. Venezuela (Orinoco drainage): ANSP 135598 (3: 94.4$126.2 \mathrm{~mm} \mathrm{SL})$, río Cauca $\left(07^{\circ} 07^{\prime} \mathrm{N} 65^{\circ} 00^{\prime} \mathrm{W}\right)$, Bolivar, 28 Jan 1977 , J. Bohlke et al. ANSP 139897 (8: 95.9-135.7 mm SL), río Mato $\left(07^{\circ} 08^{\prime} \mathrm{N} 65^{\circ} 10^{\prime} \mathrm{W}\right)$, Bolivar, 01 Feb 1977, J. Boehlke et al. ANSP 141581 (11: 87.5-118.0 mm SL), Jabillal (06 $\left.57^{\circ} \mathrm{N} 64^{\circ} 50^{\prime} \mathrm{W}\right)$, Bolivar, 25 Jan 1977, J. Boehlke et al. ANSP 150430 (3: 74.6-84.6 mm SL), río Caura $\left(07^{\circ} 07^{\prime} \mathrm{N} 65^{\circ} 00^{\prime} \mathrm{W}\right)$, Bolivar, 29 Jan 1977, J. Boehlke et al. ANSP 159332 (13: 82.3-105.0 mm SL), Caño Caima, Bolivar, 29 Nov 1985, B. Chernoff et al. ANSP 159366 (1: 100.0 mm SL), río 


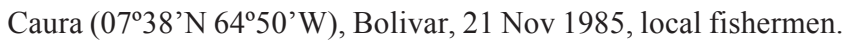
ANSP 163482 (1: 124.5 mm SL), río Portuguesa, Guarico, 22 Jul 1985, B. Chernoff et al. ANSP 165370 (2: 197.5-229.0 mm SL), río Claro, San Fernando de Apure-Puerto ( $07^{\circ} 10^{\prime} 00^{\prime \prime} \mathrm{N} 65^{\circ} 25^{\prime} 00^{\prime}$ 'W), Apure, 07 Nov 1989, S. Schaefer et al. ANSP 166448 (1: $105.0 \mathrm{~mm}$ $\mathrm{SL})$, río Orinoco $\left(08^{\circ} 11^{\prime} 25^{\prime} \mathrm{N} 63^{\circ} 28^{\prime} 20^{\prime} \mathrm{W}\right), 14 \mathrm{Mar} 1987, \mathrm{M}$. Rodriguez et al. ANSP 166449 (1: $110.9 \mathrm{~mm} \mathrm{SL}$ ), río Orinoco (06 06'00"N 6345'50"W), 19 Jan 1988, M. Rodriguez et al. ANSP 166887 (1: 199.0 mm SL), río Orinoco, Bolivar, 13 Apr 1988, M. Rodriguez et al. MZUSP 27964 (3, 62.9-151.0 mm SL), río Cunaviche, Apure, 22 Jan 1983, R. Vari et al. USNM 250625 (4: 102.6-177.0 mm SL), río Caracol (08³4'N 67³0’W), Fundo Masaguaral, Guarico, 21 Apr 1983, R. Vari et al. USNM 258027 (4: 73.6-153.3 mm SL), caño Falcon $\left(08^{\circ} 14^{\prime} \mathrm{N} 67^{\circ} 35^{\prime} \mathrm{W}\right)$, San Fernando, Masaguaral, 21 Apr 1983, R. Vari et al. Leporinus lacustris: Brazil (upper Paraná drainage): MZUSP 3458 (holotype: $113.1 \mathrm{~mm} \mathrm{SL}$ ), Pirassununga, São Paulo, 1943, O. Schubart. MZUSP 1449 (paratype: $86.6 \mathrm{~mm}$ SL), Olímpia, São Paulo, 1916, E. Garbe. MZUSP 3458a (paratypes: 90.0-105.0 mm SL), Olímpia, São Paulo, 1916, E. Garbe. MZUSP 1466 (1: $124.3 \mathrm{~mm}$ SL), rio Mogi-Guassu, Emas, São Paulo, 1907. MZUSP 3706 (1: 140.4 mm SL), rio MogiGuassu, Pirassununga, São Paulo, 1941, O. Schubart. MZUSP 42621 (1: $110.3 \mathrm{~mm} \mathrm{SL}$ ), Lagoa of rio Tietê, beneath Promissão dam, Promissão, São Paulo, 10 Nov 1978, H. A. Britski. MZUSP 43008 (1: $58.2 \mathrm{~mm} \mathrm{SL}$ ), rio Samambaia, tributary of rio Paraná, Taquaruçu,

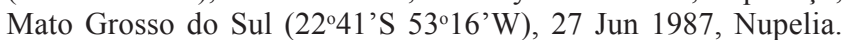
MZUSP 43009 (2: 131.5-139.6 mm SL), rio Samambaia, tributary of rio Paraná, Taquaruçu, Mato Grosso do Sul (22 $\left.2^{\circ} 41^{\prime} \mathrm{S} 53^{\circ} 16^{\prime} \mathrm{W}\right)$, 27 Nov 1987, Nupelia. MZUSP 43024 (1: 104.3 mm SL), Reservatório de Itaipu, rio Paraná, Santa Helena, Paraná (24⒌' 'S $\left.54^{\circ} 21^{\prime} \mathrm{W}\right), 10$ Nov 1985, Nupelia. MZUSP 43028 (2: 114.0-146.9 $\mathrm{mm} \mathrm{SL}$ ), Reservatório de Itaipu, near rio Tatuí, rio Paraná, Guairá, Paraná (240ㅇ'S 54²0'W), 29 Ago 1989, Nupelia. MZUSP 43047 (1: $141.1 \mathrm{~mm} \mathrm{SL}$ ), rio Invinheima, tributary of rio Paraná, Taquaruçu,

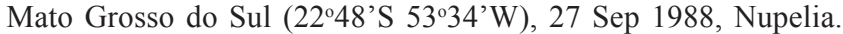
MZUSP 43048 (1: $139.2 \mathrm{~mm} \mathrm{SL})$, rio Invinheima, tributary of rio

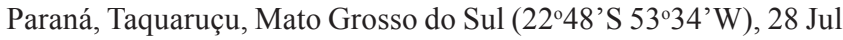
1988, Nupelia. MZUSP 43058 (2: 69.0-72.0 mm SL), rio Iguatemi, tributary of rio Paraná, Mundo Novo, Mato Grosso do Sul (235'ㅇ 54ำ1'W), 23 Ago 1988, Nupelia. MZUSP 43059 (2: 112.4-124.5 $\mathrm{mm} \mathrm{SL}$ ), rio Iguatemi, tributary of rio Paraná, Mundo Novo, Mato

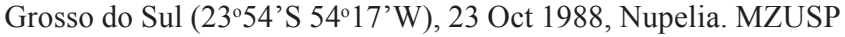
43067 (1: 196.8 mm SL), Lagoa do Guaraná, rio Samambaia, tributary of rio Paraná, Taquaruçu, Mato Grosso do Sul (22\%43'S 531''), 25 Ago 1988, Nupelia. MZUSP 43068 (1: 134.5 mm SL), Lagoa do Guaraná, rio Samambaia, tributary of rio Paraná,

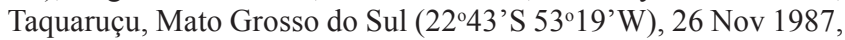
Nupelia. MZUSP 43070 (1: 76.1 mm SL), Ilha Mutum, rio Paraná,

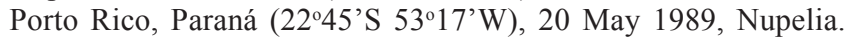
MZUSP 43072 (1: $167.0 \mathrm{~mm}$ SL), Lagoa Fechada, rio Samambaia, tributary of rio Paraná, Mato Grosso do Sul (22 $41^{\circ}$ 'S $\left.53^{\circ} 13^{\prime} \mathrm{W}\right), 27$ Ago 1988, Nupelia. MZUSP 43073 (1: 102.0 mm SL), Lagoa dos Patos, rio Invinheima, tributary of rio Paraná, Taquaruçu, Mato Grosso do Sul, 27 Jun 1988, Nupelia. MZUSP 43075 (1: 144.0 mm SL), rio Invinheima, Porto Tigre, tributary of rio Paraná, Naviraí,

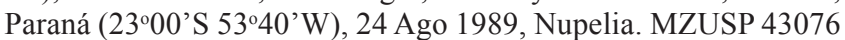
(1: $150.4 \mathrm{~mm} \mathrm{SL}$ ), rio Iguatemi, tributary of rio Paraná, Mundo

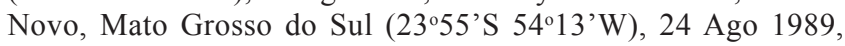
Nupelia. MZUSP 48410 (40: 106.0-155.0 mm SL), Ribeirão dos Porcos, tributary of rio Tietê, Mar de Espanha, Borborema, São Paulo, 12 Dec 1975, J. C. Garavello. MZUSP 48411 (2: 119.7$203.7 \mathrm{~mm} \mathrm{SL}$ ), tributary of rio Itaqueri, rio Piracicaba basin, $3 \mathrm{~km}$ from Águas de São Pedro, São Paulo, 25 Oct 1983, A. Copriva. MZUSP 48414 (1: 95.0 mm SL), rio Mogi Guaçu, Emas,
Pirassununga, São Paulo, Apr 1962. MZUSP 48415 (1: 113.6 mm SL), rio Mogi-Guassu, Emas, São Paulo, 1-6 May 1963, Exp. Depto. Zool. MZUSP 48416 (1: 109.5 mm SL), Córrego Fundo, Murutinga do Sul, São Paulo, 22 Dec 1974, A. Storti. MZUSP 48417 (2: 104.3 $108.8 \mathrm{~mm}$ SL), Poço of córrego do Abrigo, Jupiá dam, Mato Grosso do Sul, 28 Dec 1966, H. A. Britski. MZUSP 48418 (1: 94.7 mm SL), rio Mogi-Guassu, Emas, São Paulo, Mar 1953, W. Bockermann. MZUSP 48419 (2: 51.3-73.6 mm SL), Lagoa of rio Paraná, in front of Jupiá, Mato Grosso do Sul, 11-23 Sep 1964, Exp. Depto. Zool. MZUSP 48463 (9: 141.6-172.3 mm SL), rio Grande, Marimbondo, São Paulo, 20 Nov 1975, Cetesb. MZUSP 48505 (7: 101.5-179.8 $\mathrm{mm} \mathrm{SL}$ ), rio Itaqueri tributary of rio Piracicaba, Águas de São Pedro, São Paulo, 14 Nov 1983, J. C. Garavello et al. MZUSP 48412 (1: $154.6 \mathrm{~mm} \mathrm{SL}$ ), Reservatório de Volta Grande, rio Grande, Miguelópolis, São Paulo, 6-7 Nov 1975, Cetesb. MZUSP 48740 (1: 114.3 mm SL), rio Mogi Guaçu, Emas, Pirassununga, São Paulo, 29 Jun 1962, Exc. Depto. Zool. Sec. Agric. MZUSP 53955 (2: 134.0-135.0 mm SL), Reservatório de Barra Bonita, rio Piracicaba, Santa Maria da Serra, São Paulo, 1994-1995, R. A. M. Silvano. MZUSP 63673 (1: 95.6 mm SL), rio Mogi-Guassu, Estação Experimental, Pirassununga, São Paulo, May 1940, A. Aguirre. MZUSP 63685 (2: 95.5-106.2 mm SL), Olímpia, São Paulo, Nov 1916, E. Garbe. MZUSP 79327 (1: 104.8 mm SL), rio Tietê, Reservatório de Promissão, Promissão, São Paulo, Jan 2000, W. S. Smith. MZUSP 79347 (2: 119.7-133.8 mm SL), rio Tietê, Reservatório de Ibitinga, near rio Jacaré-Guaçu, Iacanga, São Paulo (2152'12"S 48 59'05'W), Jul 2000, W. S. Smith. MZUSP 83388 (6: 115.8-125.7 mm SL), rio Tietê, dowstream of Reservatório da UHE Bariri, Bariri, São Paulo, 3 Nov 2003, A. Akama. Brazil (Paraguay drainage): MZUSP 25252 (2 : 98.3-107.1 mm SL), Lagoas at Fazenda Santo Antônio do Paraíso, Piquiri-Itiquira basin, Itiquira, Mato Grosso, 24-29 Oct 1978, J. C. Oliveira. MZUSP 28561 (1: $94.5 \mathrm{~mm} \mathrm{SL}$ ), rio Taquari, near the city, Coxim, Mato Grosso, Dec 1983, A. Carvalho Filho. MZUSP 36361 (1: 194.0 mm SL), Corixão Capão Grande, Nhecolândia, Corumbá, Mato Grosso, Sep 1985, G. M. Mourão et al. MZUSP 36421 (2: 101.0-150.9 mm SL), Baía do Cemitério, Fazenda Nhumirim, Nhecolândia, Corumbá, Mato Grosso do Sul, Ago 1985, G. M. Mourão \& R. A. Mauro. MZUSP 36427 (2: 84.5-88.4 mm SL), Baía 39, Faz. Nhumirim, nhecolândia, Corumbá, Mato Grosso do Sul, May 1985, E. K. Bastos. MZUSP 36430 (1: 71.5 mm SL), Baía 74, Fazenda Nhumirim, Nhecolândia, Corumbá, Mato Grosso do Sul, Jul 1985, E. K. Bastos. MZUSP 36744 (10: 81.6-94.7 mm SL), Lagoas at Fazenda Santo Antônio do Paraíso, Piquiri-Itiquira basin, Itiquira, Mato Grosso, 19-20 Sep 1980, J. C. Oliveira et al. MZUSP 38164 (2: 86.3-118.2 mm SL), rio Cassange, road Transpantaneira, Poconé, Mato Grosso, 29 Jul 1978, F. A. Machado. MZUSP 44339 (1: 82.3 mm SL), Creek on road Barra do Bugres to Cáceres, Barra do Bugres, Mato Grosso, 11 Ago 1991, Exp. MZUSP/USNM/MCP. MZUSP 48303 (6: 55.5$84.0 \mathrm{~mm}$ SL), Fazenda Santo Antônio, Pantanal do Paiaguás, Mato Grosso do Sul, T. Liparelli. MZUSP 48356 (2: 60.0-80.5 mm SL), Fazenda Santo Antônio, Pantanal do Paiaguás, Mato Grosso do Sul, T. Liparelli. MZUSP 48413 (1: 134.5 mm SL), Ranchão da Lagoa, Santo Antônio de Leverger, Mato Grosso, 8 Mar 1977, Cepipam. MZUSP 48420 (1: 141.4 mm SL), Transpantaneira road, Poconé, Mato Grosso, 21-23 Feb 1977, Cepipam. MZUSP 48421 (2: 125.7-129.6 mm SL), rio Paraguay, Descalvados, Cáceres, Mato Grosso, 22-24 Jan 1977, Cepipam. MZUSP 58438 (4: 60.0-96.0 mm SL), Campo do Jofre, Poconé, Mato Grosso, Feb 1977, Cepipam. MZUSP 59669 (3: 105.0-112.0 mm SL), Brejo da Santa Sofia, Aquidauana, Mato Grosso do Sul (19³5'89''S 56 20'47' W), 3 Sep 1998, A. Machado \& B. Chernoff. MZUSP 78837 (1: 66.5 $\mathrm{mm} \mathrm{SL}$ ), Borrow pits on road from Caceres to Porto Estrela, Porto Estrela, Mato Grosso, 27 Feb 2002, H. A. Britski et al. MZUSP 
90186 (1: 61.8 mm SL), Rio Sepotuba, Cáceres, Mato Grosso (15'47'33"S 57³9'20"W), 2 Mar 2002, H. A. Britski et al. MZUSP 90457 (1: $154.4 \mathrm{~mm}$ SL), rio Sepotuba, Cáceres, Mato Grosso (15'43'53"S 57'39'53' 'W), Mar 2002, H. A. Britski et al. Paraguay (Paraguay drainage): MZUSP 54029 (1: $48.8 \mathrm{~mm} \mathrm{SL}$ ), río Paraguay, Puerto Voluntad, at Estancia Voluntad, Puerto Voluntad, Alto Paraguay, Paraguay, 6 Jun 1997, M. T. Piza et al. Leporinus subniger: Ecuador (upper Amazon drainage): ANSP 119928 (1), Quebrada of río Jivino, tributary of Napo, 08 Aug 1969, Hugghins.

\section{Acknowledgments}

The new species was discovered by Paulo Cesar Venere, to whom we are grateful for depositing material at MZUSP. We are also in debt to Carine Chamon, Leandro Sousa, Marcelo Melo and Lesley Souza, who collected additional material during the Central Brazil Expedition, founded by All Catfish Species Inventory (NSF DEB-0315963). We are also grateful to Flávio Lima, Mark Sabaj Pérez and two anonymous reviewers for suggestions to the manuscript; and to Mark Sabaj Peréz, John Lundberg, Richard Vari and David Santana for assistance during visit of JLOB to ANSP and USMN in Jan 2007. For loan of specimens we thank Mark Sabaj Peréz. The authors were funded by CNPq (HAB) and FAPESP (06/537377 - JLOB).

\section{Literature Cited}

Böhlke, J. 1958. Studies on fishes of the family Characidae. No 14. A report on several extensive recent collections from Ecuador. Proceedings of the Academy of Natural Sciences of Philadelphia, 110: $1-121$

Borodin, N. A. 1929. Notes on some species and subspecies of the genus Leporinus Spix. Memoirs of the Museum of Comparative Zoology at Havard College, 1 (3): 269-290.

Britski, H. A. 1997. Descrição de duas espécies novas de Leporinus dos rios Araguaia e Tocantins, e comentários sobre as demais espécies do gênero assinaladas na bacia (Ostariophysi, Characiformes, Anostomidae). Comunicações do Museu de Ciências e Tecnologia da PUCRS, série Zoologia, 10: 27-43.
Britski, H. A \& J. C. Garavello. 1978. Sobre Leporinus octofasciatus Steindachner da bacia do Paraná (Pisces, Anostomidae). Papeis Avulsos do Departamento de Zoologia, 31 (16): 235-250.

Britski, H. A. \& J. C. Garavello. 2005. Uma nova espécie de Leporinus Agassiz, 1829, da bacia amazônica (Ostariophysi: Characiformes: Anostomidae). Comunicações do Museu de Ciências e Tecnologia da PUCRS, série Zoologia, 18 (2): 75-82.

Campos, A. A. 1945. Contribuição ao estudo das espécies brasileiras do gênero Leporinus. Papeis Avulsos do Departamento de Zoologia, 5 (16): 141-158.

Castelnau, F. 1855. Animaux nouveaux ou rares recueillis pendant l'expédition dans les parties centrales de l'amérique du Sud, de Rio de Janeiro à Lima et de Lima au Pará 2. Poissons. Introduction; I-XII; 1-112; 50 pls.

Eigenmann, C. H. \& F. Ogle. 1907. An annotated list of characin fishes in the United States National Museum and the Museum of Indiana University, with descriptions of new species. Proceedings of the United States Natural Museum, 33: 1-36.

Fowler, H. W. 1943. A collection of fresh-water fishes from Colombia, obtained chiefly by Brother Nicéforo Maria. Proceedings of the Academy of Natural Sciences of Philadelphia, 95: 223-266.

Garavello, J. C. 1979. Revisão taxonômica do gênero Leporinus Spix, 1829 (Ostariophysi, Anostomidae). Unpublished Ph. D. Dissertation, Universidade de São Paulo, 451 pp.

Garavello, J. C. \& H. A. Britski. 2003. Family Anostomidae. Pp. 71-84. In: Reis, R. E, S. O. Kullander \& C. F. Ferraris Jr. (Eds.). Check List of the Freshwater Fishes of South and Central America. Porto Alegre, Edipucrs, 729p.

Santos, G. M. \& M. Jégu. 1989. Inventário taxonômico e redescrição das espécies de Anostomideos (Characiformes, Anostomidae) do baixo Rio Tocantins, PA, Brasil. Acta Amazônica, 19: 159-213.

Santos, G. M., M. Jégu \& B. Merona. 1984. Catálogo de peixes comerciais do baixo Rio Tocantins. Eletronorte, Brasilia, 84 p.

Santos, G. M., B. Merona, A. A. Juras \& M. Jégu. 2004. Peixes do Baixo Rio Tocantins: 20 anos depois da Usina Hidroelétrica Tucurui. Eletronorte, Brasilia, 216 p.

Valenciennes, A. 1850. In: Cuvier \& Valenciennes, 1850. Histoire Naturelle des Poissons, Paris et Strasbourg, 22: 532pp, pls. 634-650.

Accepted January 2008 Published 31 March 2008 